\title{
TECHNO-ECONOMICS OF SEAWEED FARMING ALONG THE COASTS OF KELANTAN, EAST COAST PENINSULAR MALAYSIA
}

\author{
Phang Siew-Moi ${ }^{1,2} *$, Yeong Hui-Yin ${ }^{1}$, Hanafi Hussin ${ }^{3,}{ }^{1}$, Lim Phaik-Eem ${ }^{1}$, You Hack- \\ Churl $^{4}$ and Juan Joon-Ching ${ }^{5}$ \\ ${ }^{1}$ Institute of Ocean and Earth Sciences, University of Malaya, Kuala Lumpur \\ ${ }^{2}$ Institute of Biological Sciences, University of Malaya, Kuala Lumpur \\ ${ }^{3}$ Department of Southeast Asian Studies, Faculty of Arts and Social Sciences, University of Malaya, Kuala Lumpur \\ ${ }^{4}$ Pegasus International Inc., Republic of Korea \\ ${ }^{5}$ Nannotechnology and Catalysis Research Centre, University of Malaya, Kuala Lumpur \\ Corresponding authors: Phang Siew-Moi (phang@um.edu.my); Hanafi Hussin (hanafih@um.edu.my)
}

\begin{abstract}
A Grand Challenge programme was initiated at the University of Malaya under the Equitable Society Research Cluster, to introduce seaweed farming to the coastal communities at Bachok district, Kelantan. Cultivation trials of selected commercial seaweeds like Kappaphycus (source of carrageenan), Gracilaria (source of agar), Gelidium (source of agar and pulp) and Ulva (salad) will be conducted using on-shore and off-shore systems, and the data collected is used for the techno-economics analysis. This paper discusses the techno-economics of various cultivation systems, as well as the importance of community empowerment, as a guide to the formulation of a roadmap for the integration of seaweed farming into the Bachok coastal communities.
\end{abstract}

Abstrak Satu Program Grand Challenge telah dimulakan dibawah Kluster Penyelidikan Equitable Society di Universiti Malaya bagi memperkenalkan pengkulturan rumpair laut kepada komuniti persisiran pantai di daerah Bachok, Kelantan. Percubaan pengkulturan rumpair laut terpilih seperti Kappaphycus (sumber carrageenan), Gracilaria (sumber agar), Gelidium (sumber agar dan pulpa) dan Ulva (salad) akan dilaksanakan dengan menggunakan sistem tepi pantai (on-shore) dan luar pantai (off-shore), dan data-data yang dikumpulkan ini digunakan dalam analisis tekno-ekonomi. Makalah ini membincangkan teknoekonomi bagi pelbagai sistem pengkulturan serta kepentingan pemberdayaan komuniti, sebagai panduan kepada perumusan pelan hala tuju untuk mengintegrasikan pengkulturan rumpair laut ke komuniti pesisiran pantai Bachok.

Keywords: seaweed farming, off-shore system, on-shore system, techno-economic analysis, community participation, Kelantan

\section{INTRODUCTION}

The seaweed industry in Malaysia is focussed mainly around the Semporna area of Sabah, East Malaysia. Farming of the carrageenophytes Eucheuma J. Agardh and Kappaphycus Doty by both indigenous and migrant coastal communities at Semporna, was initiated in the 1970s (Sade et al., 2006; Hurtado et al., 2014). The global increase in demand for carrageenan and the seaweed feedstocks, led to the expansion of farming activities and areas in the Brunei-IndonesiaMalaysia-Philippines (BIMP) region, which is located within the Coral Triangle. Kappaphycus, which is one of the few 
seaweeds that produce kappa-carrageenan, is intensively cultivated in the Coral Triangle, which supplies up to $90 \%$ of the global kappa-carrageenan (Hurtado et al., 2014). Other seaweeds include Eucheuma, Gracilaria and to a much smaller extent, Gracilariopsis heteroclada and Caulerpa spp. (Hurtado et al., 2014).

The introduction of seaweed farming in the Philippines in the mid-1960s had resulted in improved livelihoods on the poor coastal populations (Hurtado et al., 2013; 2015). In the late 1980s farming of Eucheuma was introduced to Indonesia and Malaysia, resulting in similar observations of improved livelihoods of the coastal communities (Sade et al., 2006). A cooperative approach was implemented by the Sabah Fisheries Department, which comprised the womenfolk of the fishing communities in Sabah, who were trained to cultivate Kappaphycus and to produce cottage-scale products (Sade et al., 2006). In 2012, the Malaysian government implemented the National Key Economic Areas (NKEA) with seaweed farming as one of 13 entry point projects (EPP). This seaweed initiative aimed to increase seaweed production to 150,000 tons by 2020, with 12,700 job opportunities and a contribution of RM 1.4 billion in revenue (PEMANDU, 2010). This provided resources for the Seaweed Cluster Project (SCP) initiated in 2012 by the Sabah Fisheries Department and the Mini-Estate programme. An excellent evaluation of the SCP was published by Nor et al. (2016). The SCP was given the mandate to increase seaweed production, optimize farming area, improve seaweed quality and farming efficiency, while enhancing income of farmers, and reducing the environmental impact of seaweed farming (Nor et al., 2016). The evaluation exercise carried out by Mr. Adibi M. Nor showed that the "SCP outcomes were generally negative". There was low participation by the target communities, related to poor governance, low social integration of the farmers, and even "limited acceptance of new technologies". The farmers only saw a "high social status" conferred on those who participated. Recommendations to improve the SCP included increasing the farming community by legalizing existing migrant farmers; establishing seaweed cooperatives; training farmers to be entrepreneurs; and involving farmers in governance.

The sucessful establishment of offshore seaweed farming in the expansive sea areas of Sabah indicates that there is good potential of introducing seaweed farming to the coastal communities of Peninsular Malaysia. This can form the basis of a new and sustainable industry, that can enhance the livelihood of the coastal communities, especially those along the coasts of Kelantan, Terengganu, Kedah and Pahang. With this in mind, our research team initiated a project to introduce seaweed farming using both on-shore and off-shore systems to selected villagers at the Bachok district of Kelantan. This project is based at the IOES Bachok Marine Research Station (BMRS) and is funded by the Grand Challenge Programme of the Equitable Society Research Cluster, University of Malaya. This paper will review techno- 
economic approaches and studies that have been reported, followed by a description of our research approach, focussing on the farming technologies that we will introduce, and some preliminary results of culture trials.

\section{SEAWEED FARMING TECHNOLOGIES}

\section{On-shore Farming Systems (ONS)}

The early land-based or on-shore farming systems (ONS) for commercial cultivation of seaweeds was limited to use of earth ponds, especially ponds converted from shrimp farming and concrete tanks. Land-based systems, basically comprise tanks or ponds that contain water that is agitated to maintain the seaweeds in suspension and allow exposure to irradiance (Hafting et al., 2012). Nutrients can also be efficiently supplemented into a wellcontrolled culture medium. Currently only Ulva (Bolton et al., 2009), Caulerpa (Horstmann, 1983), Chondrus and Palmaria are commercially cultivated in large scale land-based systems, which have potential for producing feedstocks for functional products like fucoidins, laminarins and polyphenols that have high pharmaceutical value (Hafting et al., 2012). One constraint in tank cultivation, especially if nutrients are supplied, is the growth of fouling algae or epiphytes (Zhang et al., 2012). Presence of epiphytes can reduce the value and thus selling price of the seaweeds.

Pond cultivation has been used mainly for species of Gracilaria, an agarophytic red seaweed and the green seaweed Caulerpa which is cultivated mainly for use as a fresh salad especially in the Philippines (Trono, 1998). The system is based on vegetative propagation where cuttings of the seaweeds are either broadcasted into the ponds or planted by inserting the cuttings into the bottom of the ponds containing low levels of seawater (Trono, 1998). The ponds are then drained after the culture period of 3 to 4 months for harvest of the biomass. A portion of the harvested plants are retained for the next cycle of cultivation. Tank cultivation has been successfully employed for cultivation of several seaweed species. Ulva pertusa, a green seaweed was cultured using deep (400 $\mathrm{m})$ seawater that is rich in nitrogen and phosphorus, in Owase, Japan (Park et al., 2013). The growth rate obtained $\left(30 \mathrm{~mm}^{2}\right.$ day $^{-1}$ ) was twice that obtained with on-fifth strength PES medium. Ohno et al. (2000) successfully cultured Undaria pinnatifida using deep seawater and surface water during off season. Raceway ponds were investigated for the culture of Gracilaria in Israel (Friedlander \& Levy, 1995). However, this system may not be suitable for seaweeds that have long filamentous morphologies, as the circulation by paddlewheels may case breakage of the filaments. A solution to this is the use of ropes to tie the seaweed cuttings which are then placed in the raceway ponds. The circulating seawater flows over the cuttings which are attached to the fixed ropes, bringing nutrients but not causing breakage of the plants. The use of on-shore systems are suitable for the integration of seaweed culture with aquaculture of aquatic animals 
like shrimps, fish, abalone and oysters (Phang, 2006; Holdt \& Edwards, 2014). The Integrated Multi-Trophic Aquaculture (IMTA) has been shown to present both economic and environmental benefits to the aquaculture industry (Hadley et al., 2015). Several empirical studies, based on indoor tank systems show enhanced growth of seaweeds when cultured together with fish (Buschmann et al., 2008; Troell et al., 2009). Hadley et al. (2015) using a numerical model showed that Macrocystis pyrifera removed $75 \%$ of dissolved inorganic nitrogen compared to Ulva lactuca and Porphyra umbilicalis (5\%).

\section{OFF-SHORE FARMING SYSTEMS (OFS)}

The Off-shore Farming systems (OFS) are commonly used for commercial seaweeds that are feedstocks for production of alginate (Laminaria, Undaria, Macrocystis), carrageenan (Kappaphycus, Eucheuma), and agar (Gracilaria), as well as for food (Porphyra [Pyropia], Monostroma). The farms are near-shore but in this paper are considered as off-shore (within $1 \mathrm{~km}$ from the shoreline) as opposed to on-shore or land-based. In such cultivation systems, the seed stocks are either cuttings in which case, the system is vegetative propagation, or sporelings/plantlets derived through a hatchery/nursery system (Hurtado et al., 2014). Mature fronds are collected from the wild and brought to the nursery where laborious processes take place to facilitate release of gametes, fertilization and then germination into plantlets. The plantlets may also be derived from spores which are released through conditioning (temperature and light treatments) of the fertile fronds (Mantri et al., 2009; Yu et al., 2013). The plantlets are normally allowed to attach to ropes in the nursery tanks, and after growth to a suitable size and length, the ropes containing the young plants are out-planted in the ocean. With vegetative propagation, cuttings are tied in very innovative techniques (eg. tie-tie originating in the Philippines) to ropes and then out-planted (Hurtado et al., 2014). There are generally two methods for out-planting. One is tying the ropes or monolines equipped with floating apparatus like buoys or even discarded plastic bottles, with or without attachment to floating rafts, and anchored by various mooring systems. Another is referred to as "fixed off-bottom planting", with the use of ropes attached to stakes inserted into the sea bed (Hurtado et al., 2013). The advantage of the floating system is that the seaweeds are always immersed in the seawater, irregardless of the tidal levels. However, the seaweeds and the systems may be affected by strong waves and currents near the sea surface and during storms. The off-bottom planting system has the advantage of less strong currents near the sea bed but it is vulnerable to being silted over during heavy storms. The seaweeds are also vulnerable to predation but the invertebrates that live on the sea bed, while the floating plants are more vulnerable to epiphytism due to the higher irradiance at the sea surface (Hurtado et al., 2014). In Tanzania and other countries in the Western Indian Ocean, "die-off" of the $K$. alvarezii 
was due mainly to epiphytes and the "iceice" infections (Msuya et al., 2014). Solutions to this was the improvement of the off-bottom planting techniques and transference of the farms to deeper $(2-5 \mathrm{~m})$ waters.

\section{SEAWEED PRODUCTIVITIES}

Seaweeds are very productive, especially using mariculture techniques. The following gives the range of productivities reported for indoor laboratory-scale to outdoor culture trials. Gracilaria edulis and $G$. tenuistipitata produced growth rates of 13.57 and $19.7 \%$ FW day ${ }^{-1}$, when grown from carpospores under laboratory conditions ( $\mathrm{Yu}$ et al., 2013). Kappaphycus alvarezii and $K$. striatum were successfully cultivated using customized $4480 \mathrm{~L}$ tanks with flow -through system and screened partitions to divide the tanks into six compartments each. After 40 days' growth, maximum daily growth rate (DGR) obtained was $2.29 \pm 0.11 \%$ day $^{-1}$, with productivity of $4.55 \pm 0.34 \mathrm{~g} \mathrm{DW} \mathrm{m}{ }^{-2}$ day $^{-1}$ for $K$. alvarezii and $2.81 \pm 0.06 \% \mathrm{day}^{-1}$, and 6.17 $\pm 0.18 \mathrm{~g} \mathrm{DW} \mathrm{m}^{-2}$ day $^{-1}$ respectively for $K$. striatum (Zuldin et al.,2016)

Kappaphycus alvarezii from the Philippines, was cultured in 2-ton concrete tanks containing 1.6 ton seawater in a flowthrough system with $4 \mathrm{~kg}$ biomass per tank. After 45 days, the SGR was $0.58 \pm 0.02 \%$ day $^{-1}$ (Luhan et al., 2015) When the seaweeds were immersed in a tank containing $10 \mathrm{ppm}$ sodium nitrate for $12 \mathrm{hr}$ before culturing, the SGR increased to 1.40 $\pm 0.30 \%$ day $^{-1}$ after 45 days.
Caulerpa lentillifera was cultured in flasks under indoor conditions, and various levels of temperature and irradiance. The maximum specific growth rate (SGR) of $6.93 \pm 0.40 \%$ day $^{-1}$ was obtained at $27.5^{\circ} \mathrm{C}$ and $40 \mu \mathrm{mol}$ photons $\mathrm{m}^{-2} \mathrm{~s}^{-1}$ (Guo et al., (2015).

Ulva tepida was cultured by seeding ropes and subsequently placed in flowthrough outdoor tanks for growth. The plants were harvested after 14 days, leaving $1 \mathrm{~cm}$ lengths for the next growth cycle. The specific growth rate decreased from the 2 nd $\left(15.6 \pm 4.2 \% \mathrm{day}^{-1}\right)$ cycle to the $3 \mathrm{rd}(10.4 \pm$ $8.0 \%$ day $^{-1}$ ) cycle; and two harvest was recommended (Carl et al., 2016).

The brown seaweed Saccharina latissima was cultivated using floating raft equipped with hanging rope culture system in northwest Spain. The study showed that the seaweeds cultivated in moderately exposed site (16 $\mathrm{kg} \mathrm{FW} \mathrm{m}^{-1}$ rope; 40.2 ton FW ha ${ }^{-1}$ ) had higher yields than sheltered sites $\left(12 \mathrm{~kg} \mathrm{FW} \mathrm{m}^{-1}\right.$ rope; 30.4 ton $\mathrm{FW} \mathrm{ha}^{-1}$ ) after 119 days. This showed that light exposure and water movement was important for good growth of the Saccharina (Peteiro \& Freire, 2013).

In south-west Madagascar, $K$. alvarezii was cultivated in various sites of high and low flow conditions, using offbottom and long line planting systems (Ateweberhan et al., 2015). Average growth rate was $4.5 \pm 0.06 \%$ day $^{-1}$ being higher using the long line $\left(5.46 \pm 0.09 \%\right.$ day $^{-1}$ than the off-bottom $\left(3.99 \pm 0.07 \%\right.$ day $\left.^{-1}\right)$ system. Important factors that influenced 
the growth were sedimentation, daily water temperature variability, and their interaction. $K$. alvarezii was cultivated in three sites in the Mandapam region, southeast coast of India, using $3 \mathrm{~m} \times 3 \mathrm{~m}$ rafts (Periyasamy et al., 2015) The DGR obtained varied from $3.00 \pm 0.16$ to $3.76 \pm 0.07 \%$ day $^{-1}$.

Gracilaria changii, a Malaysian red seaweed, which produces up to $25 \%$ DW agar with gel strength of $563 \mathrm{~g} \mathrm{~cm}^{-2}$, was cultured in shallow ponds in the mangroves, in an irrrigation canal and in a shrimp farm pond. The average growth rate of cuttings tied to monofilament lines was $3.3 \pm 1.7 \%$ $\mathrm{d}^{-1}, 8.4 \pm 1.8 \% \mathrm{~d}^{-1}$ and $3.6 \pm 1.6 \% \mathrm{~d}^{-1}$ respectively. Cuttings were lost to siltation, wave action, predation and heavy epiphytisation. These studies showed that the Gracilaria changii has potential commercial application in the agar industry (Phang et al., 1996). Gracilaria sp. was cultivated using nets in ponds stocked with Penaeus monodon and Lates calcifer. The seaweed biomass doubled in one month with a stocking density of $2 \mathrm{~kg}$ per $\mathrm{m}^{2}$ (Phang, 1998).

\section{TECHNO-ECONOMIC CONSIDERATIONS IN SEAWEED FARMING}

Seaweed farming has had a long history in Asia, with the farming of Eucheuma and Kappaphycus representing a major source of revenue for the coastal communities in the BIMP/Coral Triangle. The countries within the Coral Triangle, including Malaysia, are considered as maritime nations, with long coastlines dotted by numerous islands. This has given rise to successful off-shore seaweed farms, which contribute significantly to the global seaweed trade and industry. The total production for China, Japan, South Korea, Vietnam, Philippines, Indonesia and Malaysia was 23.153 tonnes wet weight per year from 2012-2014 (Sondak et al., 2017). The latter four tropical countries produce mainly Eucheuma and Kappaphycus, while the temperate countries produce diverse seaweeds including the brown seaweeds Laminaria, Undaria and the red seaweeds Porphyra and Gracilaria.

A review of the literature reporting on the economics of seaweed farming as practiced in the region indicates that in spite of using traditional and low technology farming methods, the income generated from off-shore farms form a substantial increase in monthly incomes of the farmers. The use of simple raft systems for cultivating $K$. alvarezii in the Mandapan region of southeast India, gave DGR of 3.48 $\%$ day $^{-1}$, and based on this, the authors estimated that each farmer involved would earn USD250 to 265 per month, an increase over previous income (USD116) (Periyasamy et al., 2015). This income can be enhanced with the following: seed rafts in seawater column to avoid direct sunlight; stock at $60 \mathrm{~kg} \mathrm{FW}$ per raft $(3 \mathrm{x} 3 \mathrm{~m})$; replacement of lost seeds; and weeding.

The use of rafts for cultivation of $K$. alvarezii was carried out from 2008 to 2010, in three areas in Tamil Nadu, India, and the participating seaweed farmers were introduced to best management practices 
that included size of rafts, weight of each bunch of seedlings, tying seedlings under submerged condition, replacement of lost seedlings, etc. (Periyasamy et al., 2014). The average daily growth rates obtained ranged from 2.35 to $3.27 \%$; higher growth rates were related to better water motion. Based on a 9-month cultivation period per year, the participating farmers, using best agronomic practices, were able to earn UDS181 -272 per month after deduction of costs. Women participants were shown to have incomes from USD1129 - 2402 per year. This showed that seaweed farming is beneficial to the coastal communities and can enhance their socio-economic status, especially the womenfolk.

When $K$. alvarezii was introduced to Brazil, farmers used the "tie-tie" method adopted from the Philippines to attach the plants to the monoline used with the floating rafts (Reis et al., 2015). However, the tubular net technique replaced the "tie-tie" method and was shown to give higher daily growth rates $\left(3.48 \%\right.$ day $^{-1}$ ) and carrageenan yield (41.96\%), as well as lower farming costs and reduced epiphytism. Time for management of the tubular nets was half that given to the "tie-tie" method.

The importance of having land-based nurseries to supply seedlings of superior quality was emphasized by Hurtado et al. (2013). This would accelerate the growth of the seaweed industry through expansion of farming areas and increased productivity due to faster growth and resistance to disease and epiphytism.
The use of fertilisers have been suggested for improved yields and of biomass and carrageenan in $K$. alvarezii. A commercial extract from Ascophyllum nodosum, known as Acadian Marine Plant Extract (AMPEP) was shown to increase daily growth rate and carrageenan yield in $K$. alvarezii, as well as reduce negative effects of epiphytes (Hurtado et al., 2009; Luoreiro et al., 2010; Borlongan et al., 2011). The AMPEP was also reported to have a "vaccine-like" property (Luoreiro et al., 2012), as well as increased carrageenan yield although it did not alter the gel strength (Luoreiro et al., 2014).

Yoon et al. (2015) used three fertilisers, namely AMPEP, Gofar600 (GF) and natural seaweed extract (NSE) in concentrations of $3 \mathrm{mg} \mathrm{L}^{-1}$. GF and NSE contain varying proportions of extracts from A. nodosum, Sargassum and Laminaria. Best daily growth rate was obtained with $\operatorname{NSE}\left(5.94 \%\right.$ day $\left.^{-1}\right)>\operatorname{GF}\left(5.19 \%\right.$ day $\left.^{-1}\right)>$ AMPEP (4.55 \% day ${ }^{-1}$ ) and control (4.32\% day $\left.^{-1}\right)$. Daily medium change gave the highest growth rate $\left(6.9 \%\right.$ day $\left.^{-1}\right)$. A 2-week acclimatization of the seaweeds in concrete tanks containing NSE and at a density of 0.4 $\mathrm{g} \mathrm{L}^{-1}$, before outgrowing, also gave high growth rate $\left(7.14 \%\right.$ day $\left.^{-1}\right)$ and higher survival and epiphyte resistance of the seaweeds.

Epiphytism is a major problem in seaweed cultivation, especially with use of fertilisers. The types and occurrence of epiphytes on Gelidiella acerosa, a red seaweed that is a source of agar, were monitored on two planting systems, namely 
floating raft with lines and bottom concrete block seeded with plants (Ganesan et al., 2015). Although the number of epiphytes did not differ, the composition and density were significantly different between the two planting systems. Epiphyte density on concrete blocks was twice that on rafts, due to availability of epiphyte spores that travel downwards after release, and therefore were more available for the concrete blocks placed at the sea bottom. Exposure to wave, dessication and UVR of plants on the floating rafts reduced the epiphytes. Epiphyte density was positively correlated to salinity in the concrete block but was negatively correlated to temperature in both systems. The survival rate of Gelidiella acerosa was negatively correlated to salinity $(\mathrm{r}=0.943, \quad \mathrm{P} \leq 0.001)$ and temperature $(\mathrm{r}=0.998, \mathrm{P} \leq 0.001)$.

After 40 years of vegetative propagation method for Kappaphycus and Eucheuma in this region, Hurtado et al. (2014) suggested the use of planting materials derived from sporelings from carpsporophytes/ tetrasporophytes (Yu et al., 2013), callus tissue and protoplasts (Yeong et al., 2008). Yeong et al. (2014) developed protocols for successful callus formation and regeneration for $K$. alvarezii and shoot proliferation and culture of Gracilaria changii in airlift photobioreactors. Seabased nurseries should be established with expertise from the research institutions, for sustained supply of high quality seedlings that are tolerant to infections and have high growth rates. Existing and potential seaweed farmers have to be continuously trained to instil and improve their technical skills for greater productivities and higher income.

Although Indonesia became the largest producer of Eucheuma and Gracilaria species in the world in 2005, the farmers remain at the bottom of the value chain (Poeloengasih et al., 2014). An initiative to enhance the skills of the farmers in processing, entrepreneurship and product development was implemented in Ceningan Island, Bali, Indonesia. A survey showed that the farmers had no skills and knowledge in seaweed processing. They bleached the seaweed under a clear plastic film under the sun until the plants were bleached. The women played a major role, wooden stake construction, monoline preparation, tying the plants, out-planting, harvesting and postharvest management. The farmers were shown ways to produce products like jelly candy, cracker, jam and seaweed meatballs; all these do not require electricity, machinery and infrastructure. Business management in terms of calculating cost of production and selling price, packaging and marketing, were taught during workshops. A mentoring system was proposed based on the IDEP Foundation and Klungkung Local Government, which is essential for providing continuous assistance for community empowerment, and for uplifting the status of the seaweed farmers in the community.

\section{FARMING TECHNOLOGIES AT BMRS}

Both on-shore and off-shore farming systems will be employed at the IOES Bachok Marine Research Station (BMRS) 
located at the northeastern coast of Peninsular Malaysia, facing the South China Sea. The on-shore farming system (ONS) consists of plastic tanks with seawater circulating through a reservoir or via an overflow system (Figures 1 a, b). Raceway ponds are being constructed and will be added onto the on-shore systems to be studied. The farmed seaweeds include $K$. alvarezii, G. manilaensis and U. lactuca. A green seaweed popularly used as a salad in the Philippines and Sabah, Caulerpa lentillifera, locally known as latok, will also be included at a later stage. This is intended as a table food for local restaurants and

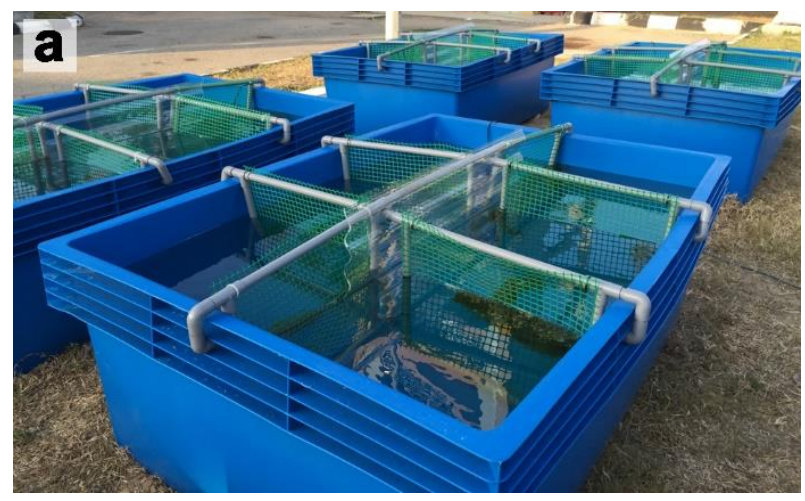

Figure 1. The on-shore farming system (ONS) a) Recirculating system and b) Overflow system
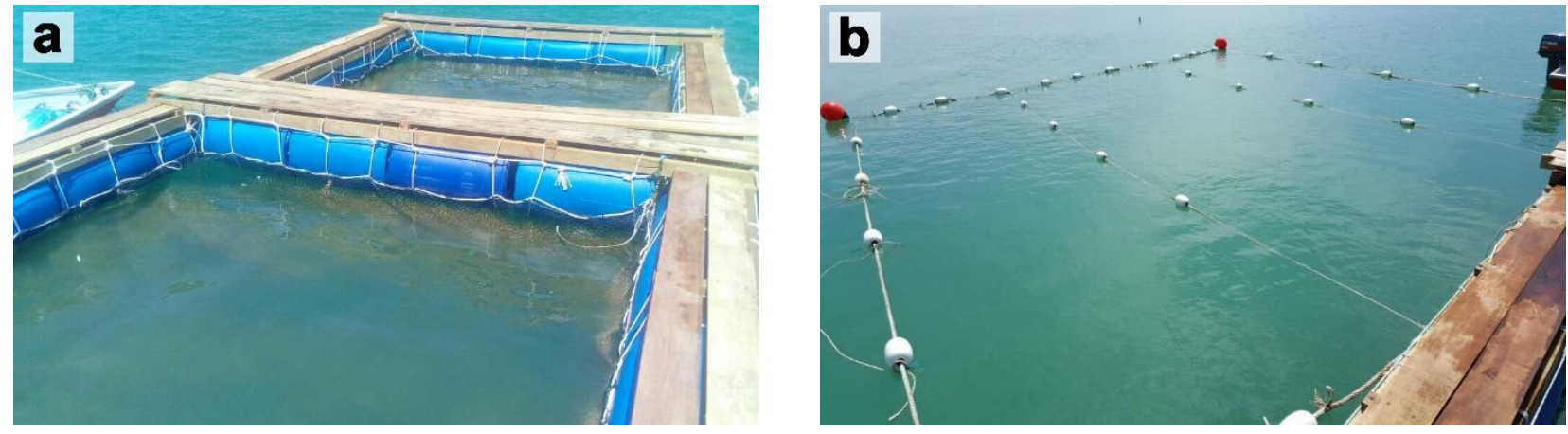

Figure 2. The off-shore system (OFS) a) Floating platforms $\left(25 \mathrm{~m}^{2}\right)$ with a net in the centre and b) Floating monolines $\left(100 \mathrm{~m}^{2}\right)$ 


\section{CULTURE TRIAL USING THE ON- SHORE FARMING SYSTEM}

Preliminary culture trials using outdoor plastic tanks were conducted. The ONS has plastic tanks with total volume 900 $\mathrm{L}$ and stocking density of $1.3 \mathrm{~g} \mathrm{~L}^{-1}$ for the recirculating system; the overflow system has a total volume of $300 \mathrm{~L}$ and a stocking density of $1.7 \mathrm{~g} \mathrm{~L}^{-1}$. The highest daily growth rates (DGR) for G. manilaensis and $U$. intestinalis obtained over the three month culture trail, were $1.5 \pm 0.6$ and $3.4 \pm 1.1 \%$ per day, respectively. Our previous studies based on culture of Ulva reticulata and Gelidium amansii in shrimp tank waste effluent, gave daily growth rates averaging $1.6 \%$ per day and $1.8 \%$ per day respectively (Rabie et al., 2015; 2016). Using a batch culture system, the DGR of $K$. alvarezii, $U$. reticulata, G. changii and $G$. edulis were $0.71,2.4,0.85$ and $0.67 \%$ per day respectively. The agar yield and gel strength of $G$. edulis and G. changii were $18 \% \mathrm{DW}$, $264 \mathrm{~g} \mathrm{~cm}^{-2}$, and $27 \% \mathrm{DW}, 284 \mathrm{~g} \mathrm{~cm}^{-2}$ respectively. In a semi-continuous culture system, the DGR of $U$. reticulata and $G$. changii was 3.38 and $0.91 \%$ per day respectively (Rabiei, 2014). The DGR obtained in the preliminary culture compared well with reported tank studies, but were below that of off-shore cultures.

This preliminary culture trial was conducted with a Bachok villager, Mr. Ahmad Nurhakim bin Sabri, who has a B.Sc degree in Marine Technology from UiTM Perlis. He will lead in the pilot-scale trial with other villagers. Each of the cultivation systems will involve two families from the Bachok vicinity. On May 2016, we organized a workshop with the two Penghulu and villagers to introduce the GC programme to the participating villagers of Kampung Kuala Rekang (Figure 3). More than 20 villagers attended and showed strong positive response to the project.

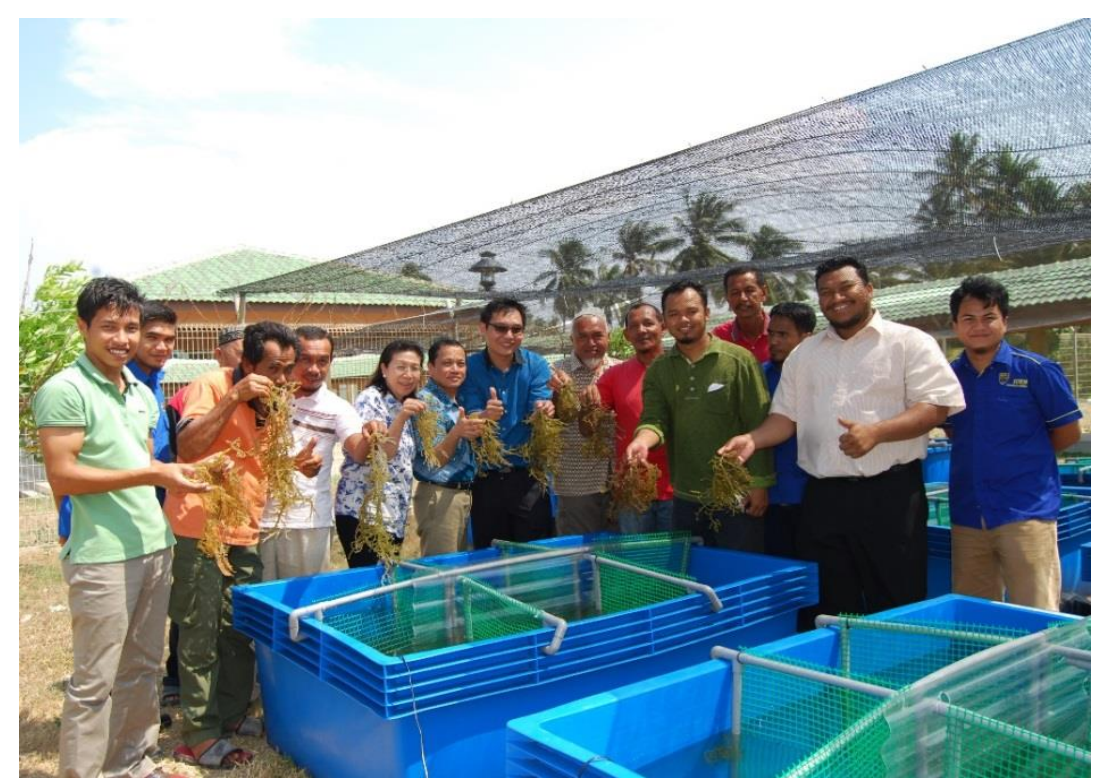

Figure 3. Workshop with the Penghulus and villagers during the Workshop to introduce the GC programme to the participating villagers of Kampung Kuala Rekang, May 2016. The seaweed being help up is Kappaphycus alvarezii, a source of carrageenan. 


\section{ROADMAP TO SUCCESSFUL INTEGRATION OF SEAWEED FARMING INTO THE BACHOK COASTAL COMMUNITY}

The east coast states of Kelantan and Terengganu comprise $5.7 \%$ and $3.7 \%$ of Malaysia's population of 31.7 million (Department of Statistics Malaysia, 7 July 2017). The median monthly household income (2014) was RM 2,716 and RM 3,777 respectively; are considered low compared with that of Kuala Lumpur (RM 7,620), Putrajaya (RM 7,512), Selangor (RM 6,214), Labuan (RM 5,684), Johor (RM 5,179), Melaka (RM 5,029) and Penang (RM 4,702). Of the 17 sustainable development goals (SDGs), Goal 1 (No poverty), Goal 8 (Decent Work and Economic Growth), Goal 9 (Industry, Innovation, Infrastructure), Goal 11 (Sustainable Cities and Communities), Goal 13 (Climate Action) and Goal 14 (Life below Water) may receive some contribution from the development of seaweed faming and industry (at least at the cottage-scale) in Kelantan and Terrenganu. The Green Economy Indicators (GEI) (2010-2015) used to measure the achievements in economic, social and environment, and to monitor the SDGs include 80 indicators addressing i) economic, demographic and social context for sustainable development, ii) the environmental and resource productivity, iii) the natural asset base, iv) the environmental dimension of quality of life and v) policy responses and economic opportunities. Our study at Bachok, Kelantan, hopes to include these elements into the roadmap to successful integration of seaweed farming to the community.

The techno-economic analysis to be carried out during the on-shore and off-shore (near-shore) farming in collaboration with selected Bachok villagers, has the following objectives: i) guiding the work-plan to achieve an economically viable outcome, ii) provide the best path to commercialisation, iii) provide an estimate of the cost of production of the final product, iv) integrate complex technical and economic information for the seaweed farming process, v) to evaluate and compare alternate processes (ONS \& OFS), to help in defining the project scale and scope for economic value, measure uncertainty of project technical and financial risks. This is useful to direct the technical development of the farming system towards establishing an economically viable process.

The economic performance of the systems can be determined by assessing the costs (capital costs like matrials for farming system, boat, shed for storage and drying seaweeds, tools, etc.; labour) against the economic benefits (revenue and cash flow). Valderrama et al. (2013) gives an excellent account of the social and economic dimensions of carrageenan seaweed farming, based on case studies conducted in six countries, namely Indonesia, the Philippines, Tanzania, Solomon Islands, India and Mexico. Farming of the 
carrageenophytes Kappaphycus and Eucheuma has been successful mainly due to low capital and materials costs, and short production cycles. Organisation of seaweed farmers into coperatves are a positive social benefit as it increases community cohesion. This can bring about improved facilities like schools. Training in entrepreneurship and seaweed processing and production of value-added products are also important strategies to increase economic benefits. Hussin and Khoso (2017), provides a good overview of the relationship between seaweed cultivation and the local communities based on the micro-level, socio-economic and cultural aspects.

The carrageenophyte Kappaphycus is used as an example for costing, since Kappaphycus and Eucheuma are the only seaweeds being commercially cultivated in Malaysia. Fresh Kappaphycus are sold for RM 0.50 per kg FW, while dry seaweeds are sold from RM 2.60 to 3.00 per $\mathrm{kg}$ DW. Export price to China is RM $4.00-5.00$ per kg DW (pers. com. Teo Kim Lai, TTJ Holdings Sdn Bhd.). Using the DGR of $0.71 \%$ FW per day of Kappaphycus, the biomass yield per growth cycle of 3 months of the $100 \mathrm{~m}^{2}$ monolines will be is $184 \mathrm{~kg}$ FW, then the annual income based on 3 growth cycles, is RM 276. At the commercial scale of 1 ha farms, the annual income may be around RM 24,000. Sade et al. (2006) reported that a typical farm in Semporna produces $1500 \mathrm{~kg}$ DW per arce cycle (3705 per kg DW per ha). This gives an annual income of RM 33,345. These two values set the limit for the construction cost of the commercial seaweed farm; this does not consider manpower, maintenance and annual operating costs, and market fluctuations.

The quality of the seaweed influences the selling price. To assist in this, the Department of Standards Malaysia with the assistance of a technical panel, has published the following, Malaysian Standard MS 2570:2014. Food grade semi-refined carrageenan - Specification; Malaysian Standard MS 2528:2013. Dried seaweed from Carrageenophytes - Specification; and Malaysian Standard MS 2467:2012. Seaweed cultivation - Code of practice. These documents will safeguard the quality of Malaysia produced seaweeds and ensure fair pricing of our exports.

Nor et al. (2016) recommended to improve the Seaweed Cluster Project (SCP) initiated in 2012 by the Sabah Fisheries Department by increasing the farming community by legalizing existing migrant farmers; establishing seaweed cooperatives; training farmers to be entrepreneurs; and involving farmers in governance. Since seaweed farming is currently not existing in the east coast of Peninsular Malaysia, the first step in the roadmap to establishing a seaweed industry there is the engagement of the local communities in the culture trials, as conducted through the Univerity of Malaya Grand Challenge Programme (GC).

The cost of fabrication of the onshore tanks and off-shore floating platforms and monolines used for the cultivation trials at the MRS can be reduced by use of local materials and manpower. The cultivation 
trials conducted with the villagers will contribute to generation of data for the techno-economic analysis as well as the socio-economic study. The villagers will also be taught the simple processing methods (viz. harvesting, drying, storage) and ways to transform the seaweeds into value-added products like soap, cosmeceuticals, food, desserts, etc. (Phang, 2010; Phang et al., 2010). Another project within the same programme is the development of a high-end product, namely a seaweed battery, and agarose, which is in high demand due to use in molecular and genetic research.

Sondak et al. (2017) reported that in 2014, the seaweeds farms in the Asia-Pacific region amounted to $2.61 \times 10^{6}$ tonnes DW. Assuming that $30 \%$ of the DW of seaweeds is carbon, then in 2014, the amount of carbon accumulated in the biomass was 0.78 $\times 106$ tonnes $\mathrm{y}^{-1}$, equivalent to $>2.87 \times 10^{6}$ tonnes $\mathrm{CO}_{2} \mathrm{y}^{-1}$. Increase in seaweed farming areas can increase $\mathrm{CO}_{2}$ removal, and if the biomass is converted to biofuel, then further contribution to climate change may be achieved. Climate related studies will also be conducted during the GC project. Carbon fixation rates and halocarbon emissions (Keng et al., 2013; Mithoo Singh et al., 2017) will be monitored using the seaweeds that are cultivated using the off-shore and on-shore cultivation systems at the IOES Bachok Marine Research Station. Marine biogenic sources of halocarbons emitted from phytoplankton and seaweeds contribute to ozone destruction leading to warming of the earth's surface. This aspect will be studied simultaneously with the positive aspects derived from $\mathrm{CO}_{2}$ drawdown by the photosynthetically efficient seaweeds.

\section{ACKNOWLEDGEMENTS}

The authors would like to acknowledge the Equitable Society Research Cluster, University of Malaya, for the generous grant GC002B-15SBS and GC002C-15SBS; Ministry of Higher Education for the HICoE Grant IOES2014F; and the staff of the IOES Bachok Marine Research Station, Fisheries Department at Kota Bharu, and the two Penghulu and villagers of the Kampong Kuala Rekang, Bachok district. This Grand Challege project would not be able to take off without all their assistance.

\section{REFERENCES}

Ateweberhan M., Rougier A. \& Rakotomahazo C. (2015). Influence of environmental factors and afrming techniques on growth and health of farmed Kappaphycus alvarezii (cottnii) in south-west Madagascar. Journal of Applied Phycology 27: 923-943.

Bolton J.J., Roberson-Anderson D.V., Shuuluka D. \& Kandjengo L. (2009). Growing Ulva (Chlorophyta) in integrated systems as a commercial crop for abalone feed in South Africa: a SWOT analysis. Journal of Applied Phycology 21: 575- 583.

Borlongan I.A.G., Tibudud K.R., Yunque D.A.T., Hurtado A.Q. \& Critchley 
A.T. (2011). Impact of AMPEP on the growth and occurrence of epiphytic Neosiphonia infestation on two varieties of commercially cultivated Kappaphycus alvarezii grown at different depths in the Philippines. Journal of Applied Phycology 23: 615-621.

Buschmann A.H., Varela D.A., HernandezGonzalez M.C. \& Huovinen P. (2008). Opportunities and challenges for the development of an integrated seaweed-based aquaculture activity in Chile: determining the physiological capabilities of Macrocystis and Gracilaria as biofilters. Journal of Applied Phycology 20: 571-577.

Carl C., Magnusson M., Paul N.A., de Nys R. (2016). The yield and quality of multiple harvests of filamentous Ulva tepida. Journal of Applied Phycology 28: 2865-2873.

Department of Statistics Malaysia. (2017) Statistics. https://www.dosm.gov.my (accessed 7 July 2017)

Friedlander M. \& Levy I. (1995). Cultivation of Gracilaria in outdoor tanks and ponds. Journal of Applied Phycology 7: 315-324.

Ganesan M., Selvaraj K., Chitra K. \& Sirajudeen S. (2015). Epiphytism differences in Gelidiella acerosa cultivated with floating rafts and concrete blocks. Journal of Applied Phycology 27: 399-412.

Guo H., Yao J., Sun Z. \& Duan D. (2015). Effect of temperature, irradiance on the growth of the green alga Caulerpa lentillifera
(Bryopsidophyceae, Chlorophyta). Journal of Applied Phycology 27: 879-885.

Hadley S., Wild-Allen K., Johnson C. \& Macleod C. (2015). Modelling macroalgae growth and nutrient dynamics for integrated multitrophic aquaculture. Journal of Applied Phycology 27: 901-916.

Hafting J.T., Critchley A.T., Cornish M.L., Hubley S.A. \& Archibald A.F. (2012). On-land cultivation of functional seaweed products for human usage. Journal of Applied Phycology 24: 385-392.

Holdt S.L. \& Edwards M.D. (2014). Costeffective IMTA: a comparison of the production efficiencies of mussels and seaweed. Journal of Applied Phycology 26: 933-945.

Horstmamnn U. (1983). Cultivation of the green alga Caulerpa racemosa, in tropical waters and some aspects of its physiological ecology. Aquaculture 32: 361-371.

Hurtado A.Q., Gerung G.S., Yasir S. \& Critchley A.T. (2014). Cultivation of tropical red seaweeds. Journal of Applied Phycology 26 (2): 707-718.

Hurtado A.Q., Montaño N.M.E. \& Martinez-Goss M.R. (2013). Commercial production of carrageenophytes in the Philippines: ensuring long-term sustainability for the industry. Journal of Applied Phycology 25: 733-742.

Hurtado A.Q., Neish I.C. \& Critchley A.T. (2015). Developments in production technology of Kappaphycus in the Phlippines: more than four decades 
of farming. Journal of Applied Phycology 27: 1945-1961.

Hurtado A.Q., Unque D.A., Tubudus K. \& Critchley A.T. (2009). Use of the Acadian marine plant extract powder from Ascophyllum nodosum (L.) in tissue culture of Kappaphycus varieties. Journal of Applied Phycology 21: 633-639

Hussin H. \& Khoso A. (2017). Seaweed cultivation amd coastal communities in Malaysia: an Overview. Asian Fisheries Science 30: 87-100.

Keng F.S.L., Phang S.M., Abd Rahman N., Leedham E.C., Hughes C., Robinson A.D., Harris N.R.P., Pyle J.A. \& Sturges W.T. (2013). Volatile halocarbon emissions by three tropical brown seaweeds under different irradiances. Journal of Applied Phycology 25: 1377-1386.

Luhan M.R.J., Avancena S.S. \& Mateo J.P. (2015). Effect of short-term immersion of Kappaphycus alvarezii (Doty) Doty in high nitrogen on the growth, nitrogen assimilation, carrageenan quality, and occurrence of ice-ice" disease. Journal of Applied Phycology 27: 917-922.

Luoreiro R.R., Reis R.P. \& Critchley A.T. (2010). In vitro cultivation of three Kappaphycus alvarezii (Rhodophyta, Areschougiaceae) variants (green, red, and brown) exposed to a commercial extract of the brown alga Ascophyllum nodosum (Fucaceae, Ochrophyta). Journal of Applied Phycology 22: 101-104.

Luoreiro R.R., Reis R.P., Berrogain F.D. \& Critchley A.T. (2012). Extract powder from the brown alga Ascophyllum nodosum (Linnaeus) Le Jolis (AMPEP): A "vaccine-like" effect on Kappaphycus alvarezii (Doty) Doty ex P.C. Silva. Journal of Applied Phycology 24: 427-432.

Luoreiro R.R., Reis R.P., Berrogain F.D. \& Critchley A.T. (2014) Effects of a commercial extract of the brown alga Ascophyllum nodosum on the biomass production of Kappaphycus alvarezii (Doty) Doty ex P.C. Silva and its carrageenan yield and gel quality cultivated in Brazil. Journal of Applied Phycology 26: 763-768.

Mantri V.A., Thakur M.C., Kumar M., Reddy C.R.K. \& Jha B. (2009). The carpospore culture of industrially important red alga Gracilaria dura (Gracilariales, Rhodophyta). Aquaculture 297: 85-90.

Mithoo-Singh P.K., Keng F.S.L., Phang S.M., Leedham E.C., Sturges W.T., Malin G. \& Abd Rahman N. (2017) Halocarbon emissions by selected tropical seaweeds: species-specific and compound specific responses under changing $\mathrm{pH}$. PeerJ 5: e2918; DOI 10.7717/peerj.2918

Msuya F.E., Buriyo A., Omar I., Pascal B., Narrain K., Ravina J.J.M., Mrabu E. \&Wakibia J.G. (2014). Cultivation and utilisation of red seaweeds in the Western Indian Ocean (WIO) Region. Journal of Applied Phycology 26: 699-705.

Nor A.M., Gray T.S., Caldwell G.S. \& Stead S.M. (2016). Is a cooperative approach to seaweed farming effectual? An analysis of the 
seaweed cluster project (SCP), Malaysia. Journal of Applied Phycology, DOI 10.1007/s10811016-1025-y.

Ohno M., Dan A., Hiraoka M., Nabeshima H. (2000). Indoor tank culture of Undaria pinnatifida using mixed deep and surface seawater in off season. Nippon Suisan Gakkaishi 66: 737-738.

Park C.S., Park K.Y., Hwang E.K. \& Kakinuma M. (2013). Effects of deep seawater medium on growth and amino-acid profile of a sterile Ulva pertusa Kjellman (Ulvaceae, Chlorophyta Journal of Applied Phycology 25: 781-786.

Performance Management and Delivery (PEMANDU) (2010). Transitioning from Agriculture to Agribusiness. In: Economic

Transformation

Programme: A Roadmap for Malaysia, pp. 512-550, Jabatan Perdana Menteri, Malaysia.

Periyasamy C, Anantharaman P. \& Subba Rao P.V. (2015). Experimental farming of Kappaphycus alvarezii (Doty) Doty with income estimates at different sites in the Mandapam region, Palk Bay, southeast coast of India. Journal of Applied Phycology 27: 935-944.

Periyasamy C., Anantharaman P. \& Balasubramanian T. (2014). Social upliftment of coastal fisher women through seaweed (Kappaphycus alvarezii (Doty) Doty) farming in Tamil Nadu, India. Journal of Applied Phycology 26: 775-781.
Peteiro C. \& Freir O. (2013). Biomass yield and morphological features of the seaweed Saccharina latissima cultivated at two diffeent sites in a coastal bay in the Atlantic cost of Spain. Journal of Applied Phycology 25: 205-213.

Phang S.M. (1998). The Seaweed Resources of Malaysia. In: Critchley A.T. \& Ohno M. (eds): Seaweed Resources of the World, pp. 79-91, Japan International Cooperation Agency, Yokosuka, Japan.

Phang S.M. (2006). Seaweed Resources in Malaysia: Current status and future prospects. Aquatic Ecosystem Health \& Management 9(2): 185-202.

Phang S.M. (2010). Potential Products from Tropical Algae and Seaweeds especially with reference to Malaysia. Malaysian Journal of Science 29(2): 160-166.

Phang S.M., Lim P.E. \& Yeong H.Y. (2010). Malaysian Seaweed Resources in the South China Sea and their Potential Economic and Ecological Applications. Journal of Science and Technology in the Tropics 6(2): 87-109.

Phang S.M., Shaharuddin S., Noraishah H. \& Sasekumar A. (1996). Studies on Gracilaria changii (Gracilariales, Rhodophyta) from Malaysian mangroves. Hydrobiologia 327: 347352.

Poeloengasih C.D., Bardant T.B., Rosyida V.T., Maryana R. \& Wahono S.K. (2014). Coastal community empowerment in processing Kappaphycus alvarezii: a case study 
in Ceningan Island, Bali, Indonesia. Journal of Applied Phycology 26: 1539-1546.

Rabiei R. (2014). Bioremediation of Shrimp Pond Effluent Using Selected Seaweeds, pp.352 . Kuala Lumpur, Malaysia: University of Malaya (Unpublish Ph.D Thesis)

Rabiei R., Phang S.M., Lim P.E., Aishah S., Sohrabipour J., Ajdari D \& Zarhenas G.A. (2016) Productivity, biochemical composition and biofiltering performance of agarophytic seaweed, Gelidium elegans (Red algae) grown in shrimp hatchery effluent in Malaysia. Iranian Journal of Fisheries Sciences 15(1): 53-74.

Rabiei R., Phang S.M., Yeong H.Y., Lim P.E., Ajdari D., Zarshenas G. \& Sohrabipour J. (2015) Bioremediation efficiency and biochemical composition of Ulva reticulata Forsskal (Chorophyta) cultivated in shrimp (Penaeus monodon) hatchery effluent. Iranian Journal of Fisheries Sciences 13(3): 621-639.

Reis R.P., das Chagas Pereira R.R. \& de Goes H.G. (2015). The efficiency of tubular netting method of cultivation for Kappaphycus alvarezii (Rhodophyta, Gigartinales) on the southern Brazilaian coast. Journal of Applied Phycology 27: 421-426.

Sade A., Ali I. \& Mohd Ariff M.R. (2006) The seaweed industry in Sabah East Malaysia. Jati - Journal of Southeast Asian Studies 11: 97-107.
Sondak C.F.A., Ang P.O. Jr., Beardall J., Bellgrove A., Boo S.M., Gerung G.S., Hepburn C.D., Dang D.H., Hu Z., Kawai H., Largo D., Lee J.E., Lim P.E., Mayakun J., Nelson W.A., Oak J.H., Phang S.M., Sahoo D., Peerapornpis Y., Yang Y. \& Chung I.K. (2017). Carbon dioxide mitigation potential of seaweed aquaculture beds (SABs). Journal of Applied Phycology DOI 10.1007/s10811-016-1022-1.

Troell M., Joyce A., Chopin T., Neori A Buschmann A.H. \& Fang J.G. (2009). Ecological engineering in aquaculture- potential for integrated multi-trohic aquaculture (IMTA) in marine offshore systems. Aquauclture 297: 1-9.

Trono G.C. Jr. (1998). The seaweed resources of the Philippines. In: Critchley A.T. \& Ohno M. (eds): Seaweed Resources of the World, pp. 47-61, Japan International Cooperation Agency, Yokosuka, Japan.

Valderrama D., Cai J., Hishamunda N. \& Ridler N. (2013). Social and economic dimensions of carrageenan seaweed farming. FAO Fisheries and Aquaculture Technical Paper, vol 580. Rome.

Yeong H.Y., Khalid N. \& Phang S.M. (2008). Protoplast isolation and regeneration from Gracilaria changii (Gracilariales, Rhodophyta). Journal of Applied Phycology 20: 641-651.

Yeong H.Y., Phang S.M., Reddy C.R.K. \& Khalid N. (2014). Production of clonal planting materials from 
Gracilaria changii and Kappaphycus alvarezii through tissue culture and culture of G. changii explants in airlift photobioreactors. Journal of Applied Phycology 26: 729-746.

Yoon Y.S., Yong W.T.L., Thien V.Y., Ng S.E., Anton A. \& Yassir S. (2015). Acclimatization of micropropagated Kappaphycus alvarezii (Doty) Doty ex Silva (Rhodophyta, Solieriaceae) in outdoor nursery system. Journal of Applied Phycology 27: 413-419.

Yu C.H., Lim P.E. \& Phang S.M. (2013). Effects of Irradiance and Salinity on the Growth of Carpospore-derived Tetrasporophytes of Gracilaria edulis and Gracilaria tenuistipitata var liui (Rhodophyta). Journal of Applied Phycology 25: 787-794.

Zhang Q.S., Tang Y.Z., Liu S.K., Zhang S.B., Lu Z.C., Cu S.H. \& Yu Y.Q. (2012). Zygote-derived seedling production of Sargassum thunbergii: focus on two frequently experienced constraints in tank culture of seaweed. Journal of Applied Phycology 24: 707-714.

Zuldin W.H., Yassir S. \& Shapawi R. (2016). Growth and biochemical composition of Kappaphycus (Rhodophyta) in customized tank culture system. Journal of Applied Phycology 28: 2453-2458. 